\title{
Impact of Public \& Foreign Direct Investment on the Economy of Bangladesh
}

\author{
Md Kamrul Islam, Sabid Khan, Zareen Haider \\ ${ }^{1}$ Lecturer A (Independent University Bangladesh), Bangladesh, \\ ${ }^{23}$ Student (Independent University Bangladesh)
}

Abstract - This paper is to investigate the impact of public investment and FDI on GDP growth of Bangladesh. The Gross Fixed Capital Formation represents public investment of our countryand we have taken FDI (inflows) as the variable while the GDP is the dependent variable. The time series data has been included here, which will be kept stationary, followed by a regression. As public investment and FDI are the independent variables, it is expected that they both have a positive relation with the dependent variable. Although, FDI may have a negative relationship to the growth. The relationship of FDI with growth rate can be used to show whether a country is in scarce of capital or not. The objective is to identify the relationship of public investment and FDI to the growth and to what extent these investments have an impact on the growth rate. By showing the estimated relationship of FDI to the GDP or growth, we are going to know whether our country is capital abundant or labor abundant. We are going to find out the answers of thesequeries through this paper.

Introduction

\section{Contents}

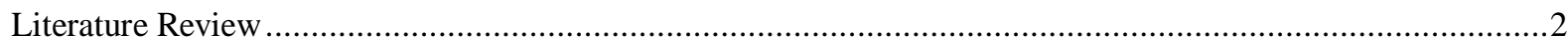

Short Discussion of Variables and Current Information ...................................................................6

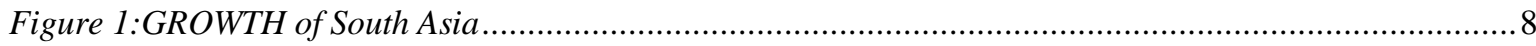

Figure 2: Graph of gross fixed capital formation of Bangladesh ............................................................

Figure 3:FDI of Bangladesh (2010-2020) ......................................................................................... 10

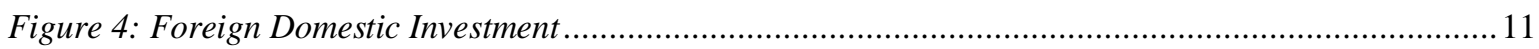

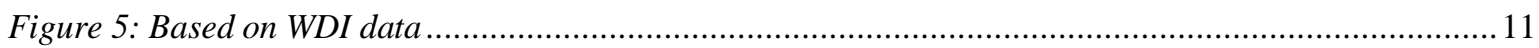

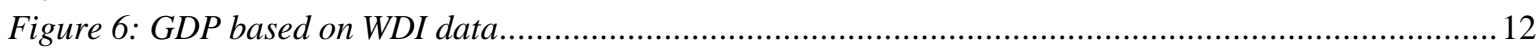

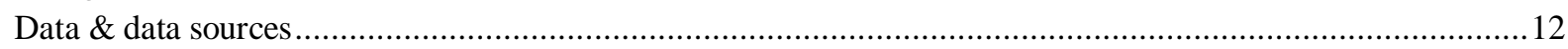

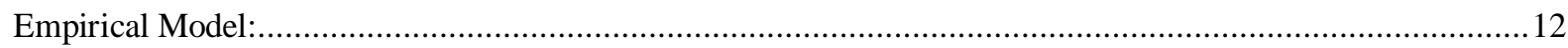

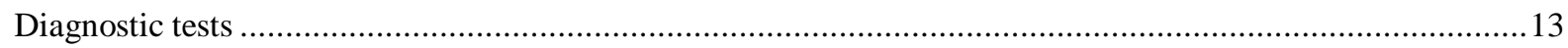

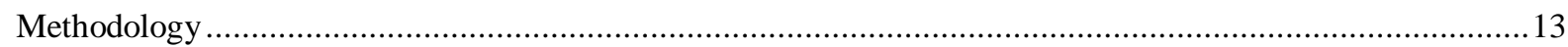

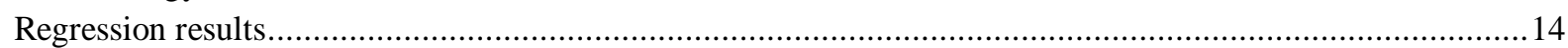

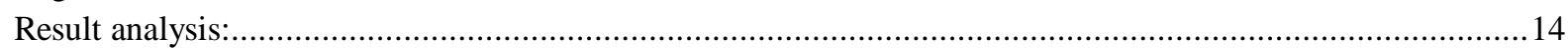

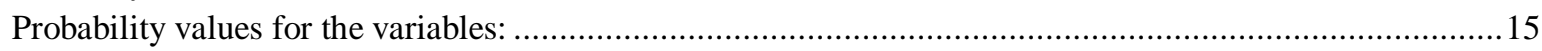

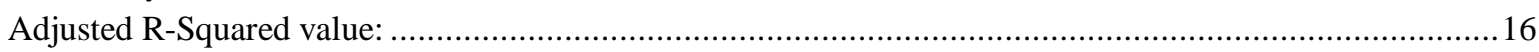

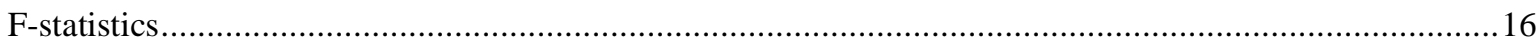

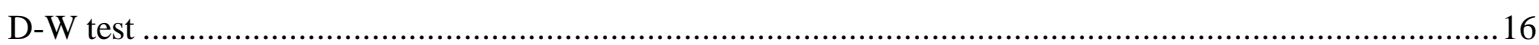

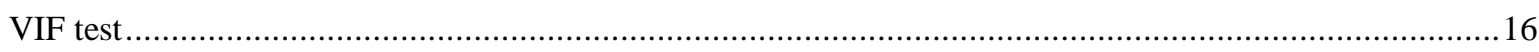

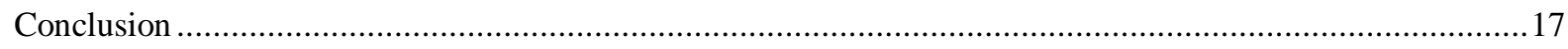

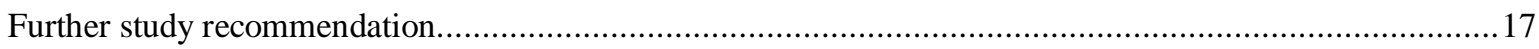

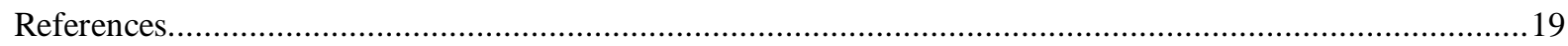

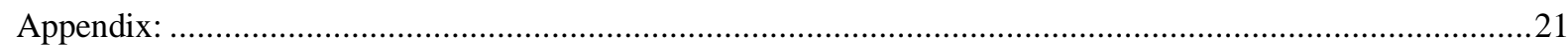

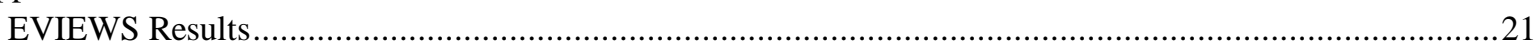


DOI: $\underline{10.51386 / 25815946 / i j s m s-v 4 i 4 p 122}$

Volume: 4 Issue: 4

July to August 2021

https://www.ijsmsjournal.org

\section{Introduction:}

Investments are basically considered as a component of GDP. In a developing country like Bangladesh, investment can be an asset to increase the growth. As we know from the nationalincome account identity, GDP of an economy is the summation of consumption, investment, government spending and net exports.

Here we have investigated the impact of public investment and FDI (foreign direct investment) on the GDP of Bangladesh.

Public investment is an element of government by which it can change the economic condition of a country. Both public and private investment are necessary for increasing GDP growth buteconomic growth of a country is mostly dependent on public investments because public investment can increase all the other types of investments (Chowdhury, Uddin, \& Uddin, 2015).

According to Dornbush, Fischer and Startz, investment means additions to the physical stock of capital such as building, machinery construction of factories additions to firm's inventories.Mankiw stated, investment consists of goods bought for future use. In Eric Doviak's view, investment consists of goods that firms and household purchase for future use as opposed to present use. Public investment is basically defined to include all government expenditure in the 'core' infrastructure sectors which raise physical capital productivity, land, transportation, power sectors, human infrastructure as well as those services that raise the productivity of labor like health, education, nutrition rather than just traditional capital expenditures (Chowdhury, Uddin, \& Uddin, 2015). Therefore, the result of this paper depends on the growth and GDP of Bangladesh.

We've already known that Bangladesh is a developing country and is considered as a land of investment. So knowing about the effects of investments in this country would be an importantfact for investors as well as the mass people.

Public investments can be considered as one of the major factors that help in increasing GDP and economic growth. Infrastructural support falls under public investment and with this support, public investment can be used to stimulate private investments. As a result, this can raise the productivity of capital and expand the overall resource availability by increasing output (Kongphet \& Masaru, 2012).

To elaborate, it can be said that if public investments in an economy are occurring properly, then it may lead to an increase in employment of a country and that should be multiplied throughout the economy (Swaby, 2007). In this way public investments have a role on economic growthas well as GDP.

It is said that Bangladesh is one of the fastest growing economies in the world but its growth rate isn't increasing from 6\%, regarding which the government has taken serious measures. In recent years, government of Bangladesh has been emphasizing the public investment for attaining higher GDP growth. So public investment in Bangladesh has been rising as it was $4.50 \%$ in 2008 and in 2015, it has increased to $6.90 \%$ of GDP. (Saidjada \& Jahan, 2018).

In the early 1980s, the world has faced a huge increase in the flow of FDI. According to UNCTAD (2012) data, global FDI flows grew from US\$50 billion to US\$1.5trillion in 2011. (Mahembe \& Odhiambo, 2014) FDI is a combined package which includes physical capital, production techniques, managerial skills, products and services, marketing expertise, advertising and business organizational process. It is highlighted that FDI plays an important role in the host country's economic growth by increasing the amount of capital which can be invested by the way oftechnological spillovers (Mahembe \& Odhiambo, 2014).

As Bangladesh is getting more flexible for investing, we can see the impact of publicinvestment and foreign direct investment (FDI) on GDP of it. Therefore we can get asignificant relationship of public investment and FDI on GDP. Many studies have suggested that there is a positive relationship of public investment and FDI on growth, which is also proven theoretically. We are also expecting a positive relationship of independent variables on dependent variable. The next part of this paper is literature review followed by data \& data sources, empirical model, diagnostic tests, methodology, results, result analysis and the last conclusion part. In the later part there will be references and appendix section.

\section{Literature Review:}

Several researches have shown positive relation between FDI and economic growth which implies that with increasing FDI in Bangladesh, the economic growth, which consists of some major elements of our country will also step towards prosperity. 
DOI: $\underline{10.51386 / 25815946 / i j s m s-v 4 i 4 p 122}$

Md Reza (2018) illustrated in his journal "The Impacts of Foreign Direct Investment Inflows on Economic Growth: Evidence from Bangladesh, that in spite of being an economically challenged nation after the liberation in 1971, Bangladesh has been able to manage and accelerate its growth through several foreign direct investments. FDI has proven to improve productivity, technology transfer, networking and skills. From 1980s to present, Bangladesh has been able to achieve greater goods for its people due to FDI. In addition to this, it can be also said that FDI influences tax revenues, government expenditure, and consumers and so on. The Korean investment has majorly contributed in the development of this country, as the LDCs are inefficient to collect funds to adjust with the inflows from foreign investors. A higher GDP attracts more FDI, which is why with time, countries like South Africa, Brazil, Vietnam and India associated with Bangladesh to invest in there. After examining several data, it was proven that economic growth highly depends on FDI. In case of long terms, FDI has a huge impact on the country's economic growth but there is no literal change when speaking of short terms. Although, all this relies on the rules and regulations of the country and also that it must be business friendly, so that the investors have faith and confidence while investing their money in Bangladesh.

A research by Afzalur Rahman (2015) has shown a different analysis between these two factors. Given that Bangladesh has a low-paid labor force, although the garments industry is reputed worldwide. The geographic location of this country provides an advantage to grow faster in the emerging markets, which is why FDI is important. Be it horizontal or vertical FDI or any other means such as joint venture, franchise and so on, Bangladesh has a scope of prospering in this field. Since the liberation in 1971, Bangladesh has been trying to improve in this sector and has quite succeeded in doing so, after the new policies adopted in 1999. Afzalur Rahman carried out a research, where data were collected from 1999 to 2013 to examine the relation between FDI and GDP, inflation rate and BOT. The results showed a very insignificant correlation between GDP and FDI but a negative relation between FDI and inflation rate and BOT. Hence, the economic growth was told to be negatively related with FDI. The reason behind this inverse relationship is the infrastructure of Bangladesh which prevents the positive outcomes of FDI affecting it. The labor forces are not well trained to match the standards of foreign companies and the privatization process is also quite inadequate. Besides, the political uneasiness and corrupted policies makes it even more difficult to create a business-friendly environment for the foreign investors.

Ahamad, Mazbahul Golam, Tanin, Fahian (2010) carried out a research on this subject where they analyzed how the economic growth of Bangladesh has changed over the years since 1971 and the factors that have influenced FDI growth to accelerate the economic condition. There were 4 models used in the research paper, based on which the relationship between FDI and economic growth will be established. As per the data, Bangladesh has started showing interest in foreign investments and introduced various policies and regulation for a smooth trade. With increasing globalization, the nation removed barriers so that foreigners can invest more. An advantage for FDIs to earn profit from this country is that the local firms are not quite developed, neither the government has that many resources which will help in growing the economy. By encouraging FDI inflow, sectors such as industry, energy, and manufacturing have improved. This has also reduced the unemployment rate as people now have more options available. All these have resulted a higher economic growth and a better image of Bangladesh which in turn, have attracted many other countries to invest, thus making the economic condition of Bangladesh even better. However, an impact of this situation has fallen in the public sector, which is not being able to rise as FDi is leading. According to the models and the research, it is suggest that FDI and economic growth is positively related. However, it is argued that it is not FDI that enhances economic growth, rather the opposite. A good economic condition attracts more foreign investors and thus the FDI inflow increases.

Muhammed Ershad Hussain and Mahfuzul Haque (2016) also suggested that FDI and economic growth have a positive relationship. The evidence collected in their research is based on various data starting from 1973-2014. According to the VECM model, a long-term relationship can be seen between these two variables. However, the model also suggests that the condition can be further improved if the policies and regulations are more standardized. Policies should be set as such that they should be business-friendly for investors to enter the market without any hesitation.

Afsana Rahman (2012) portrays Bangladesh as an agrarian country, should focus more into becoming industrial economy. In the time where globalization is considered to be a prime factor for growth and 


\section{DOI: $\underline{10.51386 / 25815946 / i j s m s-v 4 i 4 p 122}$}

development of the country and Bangladesh being a developing country is stepping forward to exchange ideas and resources with foreign countries. In the early 80 s, the foreign investments focused only on banking. By 1996, it has be attracting FDI in various other sectors such as energy and power. This was mainly because the country changed few policies and regulations which were suitable for the foreign investors. In 2010, the FDI inflow 913.2 million USD. An econometric model was created to investigate the relationship of FDI and economic growth. As Bangladesh is a developing country, it needs FDI for more development and higher GDP. When the country emerged in to this factor, the government played a vital role by making the environment less restricted for investors and introduced many policies like tax holiday scheme and zero duty rate to attract them even more. The research took several means and standard deviations into account, and analyzed data of several years to find the appropriate results. However, the results from the research stated that country policies and political stability is quite important if it wants FDI to sustain. If Bangladesh wants to continue this inflow, it has to take some effective measures and change some its regulations like reorganizing the bureaucracy. Secondly, the law and order situation should be altered so that the business environment is friendly for the foreign investors. Corruption is another reason for the hindrance that arises when investing Bangladesh. If the government wants smooth import and export, then various strategies should be implemented to reduce corruption. Not only should private sectors, the government give incentives to public sectors so that they invest and support the growth of the economy. If both these factors work together, Bangladesh will soon rise from its current position. Hence, the system and organization of the country should be set as such that all the investing parties, be it private of public should have a suitable environment so that they invest in a proper manner.

Md. Mahi Uddin, Md Niaz Murshed Chowdhury and Samim Uddin (2015) discuss the impacts of public investments in Bangladesh where they say how important public investments are for economic growth. Along with FDI, public investments, which is mainly controlled by the government carries a significant role. Although Bangladesh is a small and over populated country, its economy is rapidly growing. Unfortunately, due to low infrastructure the return from public investments is yet not satisfactory. Data from 1972 to 2011 were collected and statistically analyzed using econometric models. The results showed that public investments and economic are positively correlated. However, political uneasiness and corruption create a negative effect on these investments so that they can be utilized properly. The governing bodies should be transparent and follow the procedures accordingly to establish a business friendly environment for every investor. If the government can organize the system, the economy will indeed enhance.

With all the researches mentioned above, a conclusion can be established that FDI and public investment do have a positive relationship with economic growth. As investments increase, GDP increases which reduces unemployment. However, it is important to take the political conditions into account. Corruptions, political instability may hamper these positive effects and therefore, the government should try to keep them in control.

\section{Short Discussion of Variables and Current Information}

GDP: Gross domestic product is the total value of everything produced within a country's borders. When economists talk about the size of the economy, they refer to GDP. To avoid double counting, GDP includes the final value of the product, but not the parts that go into it. The components of GDP include personal consumption expenditures $(\mathrm{C})$, business investments $(\mathrm{I})$, government spending $(\mathrm{G})$, exports $(\mathrm{X})$ and imports (M). The equation for GDP is

$Y=C+I+G+(X-M)$

Here (X-M) shows the net exports. There are many ways to measure a country's GDP,so it's important to know all those.

Nominal GDP: This measurement is the raw measurement that includes price increases or inflation.

Real GDP: Real GDP doesn't include the inflation in the measurement. It's adjusted to inflation.

GDP growth rate: This measure shows the percentage increase in GDP and also shows the performance of the economy. The GDP growth rate changes as the economy moves through the business cycle. If the growth rate is negative, the economy contracts and it indicates a recession. If it contracts for too long, that is a depression. If the growth rate is too high, it creates inflation. 
DOI: $\underline{10.51386 / 25815946 / \mathrm{ijsms}-\mathrm{v} 4 \mathrm{i} 4 \mathrm{p} 122}$

GDP per capita: This measure is the way to compare GDP between countries because it dividesthe GDP by the number of residents and measures the standard of living. Some countries havea huge GDP only for their large population.

How does GDP affect: GDP impacts personal finance, investments and job growth. Investors look at a nation's growth rate to decide whether they should invest in the country or not. They can also compare country growth rates to find their best international opportunities. Investors purchase shares of companies that are in rapidly growing countries.

Interest rates: The central bank usually implements expansionary monetary policy to remove recession and contractionary monetary policy to control inflation. For example, if the growth rate increases, the central bank raises interest rates to stem inflation.

\section{Growth Forecast:}

In 2019, World Bank declared Bangladesh as the second highest in terms of GDP growth. The gross domestic product of Bangladesh was projected to grow 7.2\% in fiscal year 2019-2020. (Bangladesh second in South Asia in GDP growth: WB, 2019)

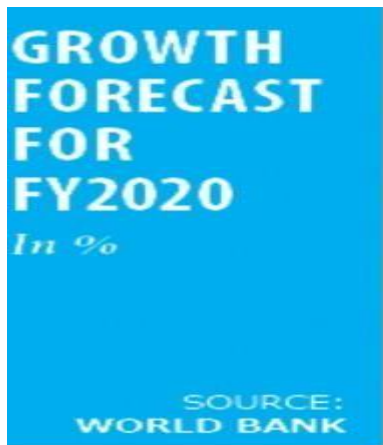

\begin{tabular}{l|l} 
Bhutan & 7.4 \\
\hline Bangladesh & 7.2 \\
\hline India & 6.9 \\
\hline Nepal & 6.4 \\
\hline Maldives & $\mathbf{5 . 5}$ \\
\hline Sri Lanka & $\mathbf{3 . 3}$ \\
\hline Afghanistan & $\mathbf{3 . 0}$ \\
\hline Pakistan & $\mathbf{2 . 4}$
\end{tabular}

Figure 1:GROWTH of South Asia

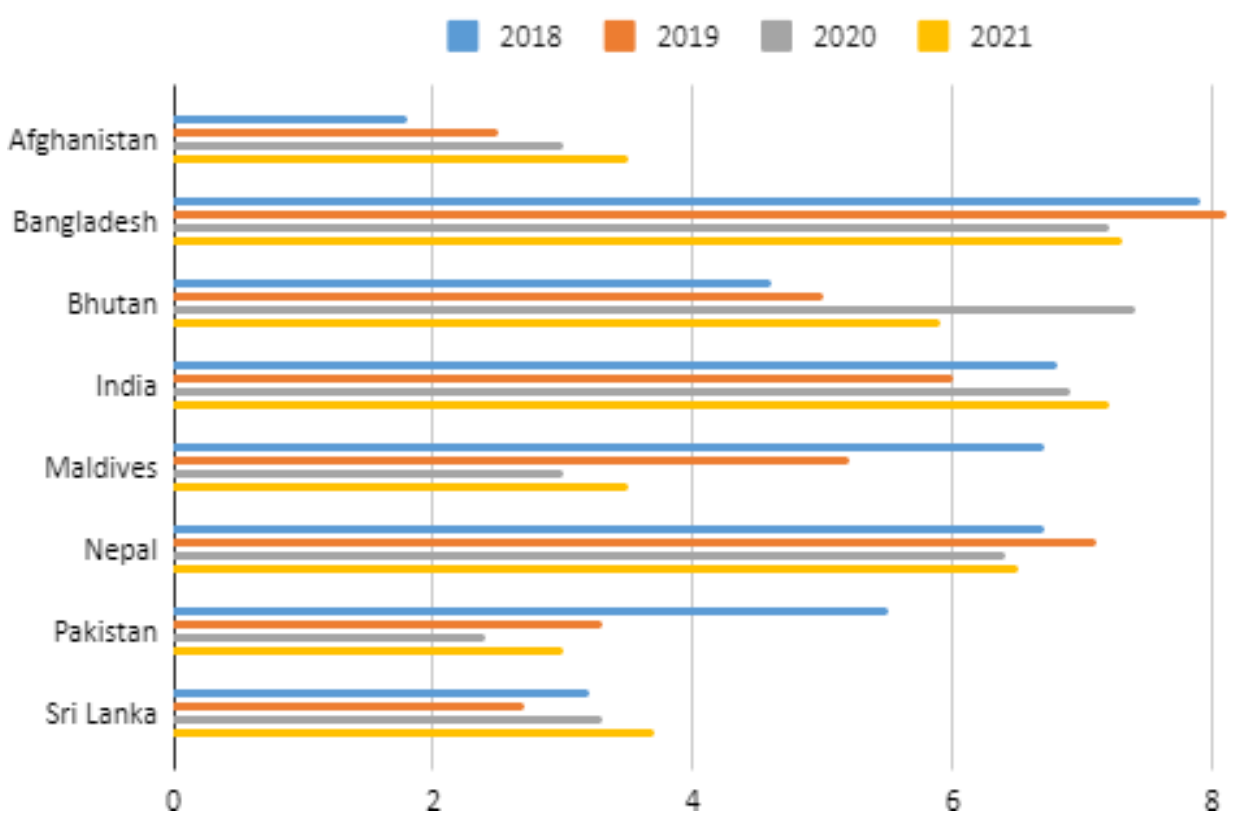

The figure shows that among the South Asian countries, Bangladesh was running the highest GDP growth 


\section{DOI: $\underline{10.51386 / 25815946 / \mathrm{ijsms}-\mathrm{v} 4 \mathrm{i} 4 \mathrm{p} 122}$}

rate in 2018 and 2019. However, in 2020 and 2021, it is not as high as the previous ones, because of the severe Corona virus pandemic situation.

Gross Fixed Capital Formation: Gross Fixed Capital Formation is the net investment. It is a component of expenditure method of calculating GDP. More specifically, it measures the net increase in fixed capital. Gross fixed capital formation includes spending on land improvements, plant, machinery, and equipment purchases; the construction of roads, railways, private residential dwellings, and commercial and industrial buildings. This part inclusion of gross fixed capital formation can also be said as public investment. (Pettinger, 2016)

Figure 2: Graph of gross fixed capital formation of Bangladesh

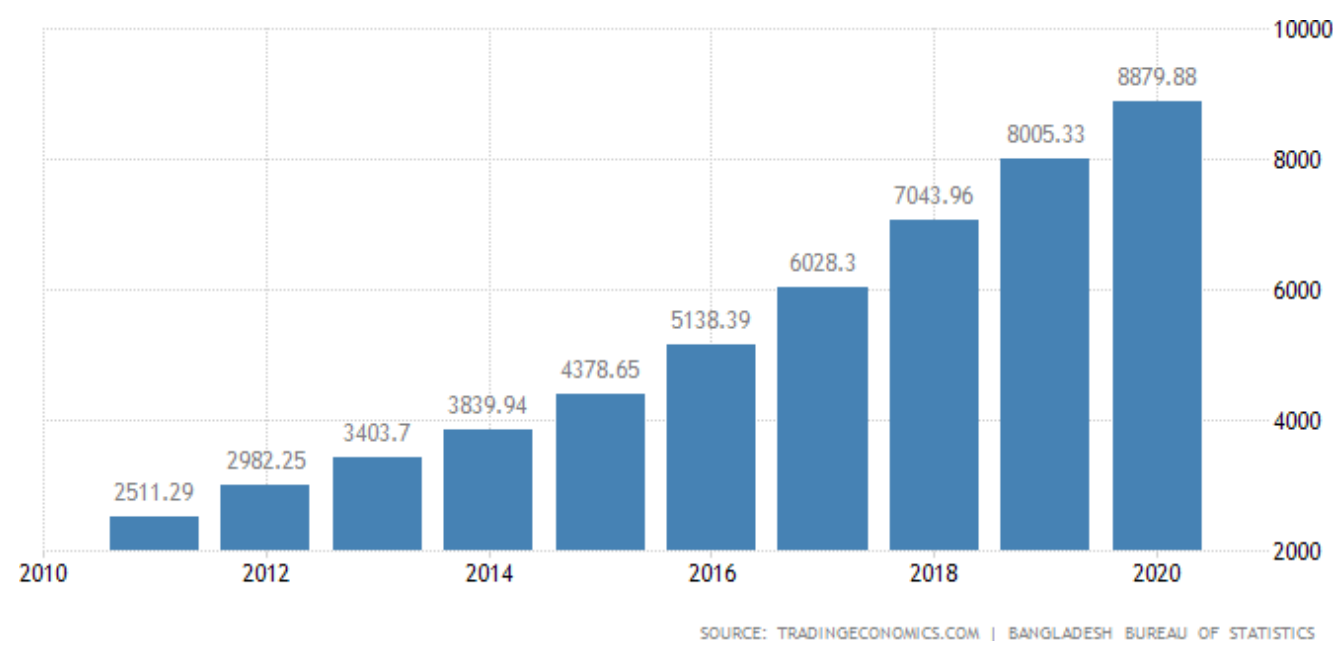

We can observe from the graph that the gross fixed capital formation is increasing in Bangladesh and it has shown a significant increase in the years of 2018, 2019 \& 2020. According to Bangladesh Bureau of Statistics, Gross Fixed Capital Formation in Bangladesh increased to 8879.88 BDT Million in 2020 from 8005.33 BDT Million in 2019. (Trading Economics, 2020)

FDI: Foreign Direct Investment occurs when an individual or business owns 10 percent or more of a foreign company. FDI is critical for developing and emerging market countries. Their companies need multinational funding to expand their international sales. Private investment is needed to their countries in infrastructure, energy and water to increase jobs and wages. (Amadeo \& Brock, The Balance, 2021)

Inflows of Foreign direct investment (FDI) to Bangladesh has declined from $31.79 \%$ to $\$ 1.15$ billion in the first half of 2020, due to the Covid-19 pandemic. (Ovi, 2020)

However, the global FDI flows fell by $49 \%$ to $\$ 399$ billion during January-June period of 2020, compared to $\$ 777$ billion during the same period of 2019, said the United Nations Conference $m$ Trade and Development (Unctad) in its report titled Global Investment Trends Monitor.

According to Bangladesh Bank's provisional data, during the January-June period of 2020, net inflow of overseas investment stood at $\$ 1.15$ billion, down by $31.79 \%$, which was $\$ 1.69$ billionin the same period in 2019 . (Ovi, 2020)

Why FDI declined rapidly: Both the global as well as Bangladesh's FDI inflows declined sharply due to the devastating impact of the pandemic. The global lockdown slowed existing investment projects and the prospect of a deep recession led multinational enterprises (MNEs) to reassess new projects. Economists also blamed the pandemic for the decline and called for preparation to overcome the situation (Ovi, 2020).

Bangladesh Investment Development Authority (Bida) executive member Nabhash Chandra Mandal said that amid the pandemic, Bangladesh's economy was doing better among the South Asian nations in terms of GDP growth and the recovery of economic fallout is better than others. He also said that FDI inflows contracted across the globe as the pandemic hit the globaleconomy and Bangladesh was not out of its impact. $\mathrm{He}$ also 


\section{DOI: $\underline{10.51386 / 25815946 / i j s m s-v 4 i 4 p 122}$}

added that the drop rate of FDI was lower than the global ones and explained hopefully that Bangladesh could recover faster than other economies (Ovi, 2020).

Ahsan H Mansur, executive director of Policy Research Institute, said to a news portal that Bangladesh's FDI inflow was in downtrend before the pandemic and it was expedited by the impact of Covid-19. This was because of slowdown of mostly the Chinese economy caused by the US-China trade war and the subsequent pandemic (Ovi, 2020).

In the following figure we can see the graphical condition of FDI in Bangladesh.

Figure 3:FDI of Bangladesh (2010-2020)

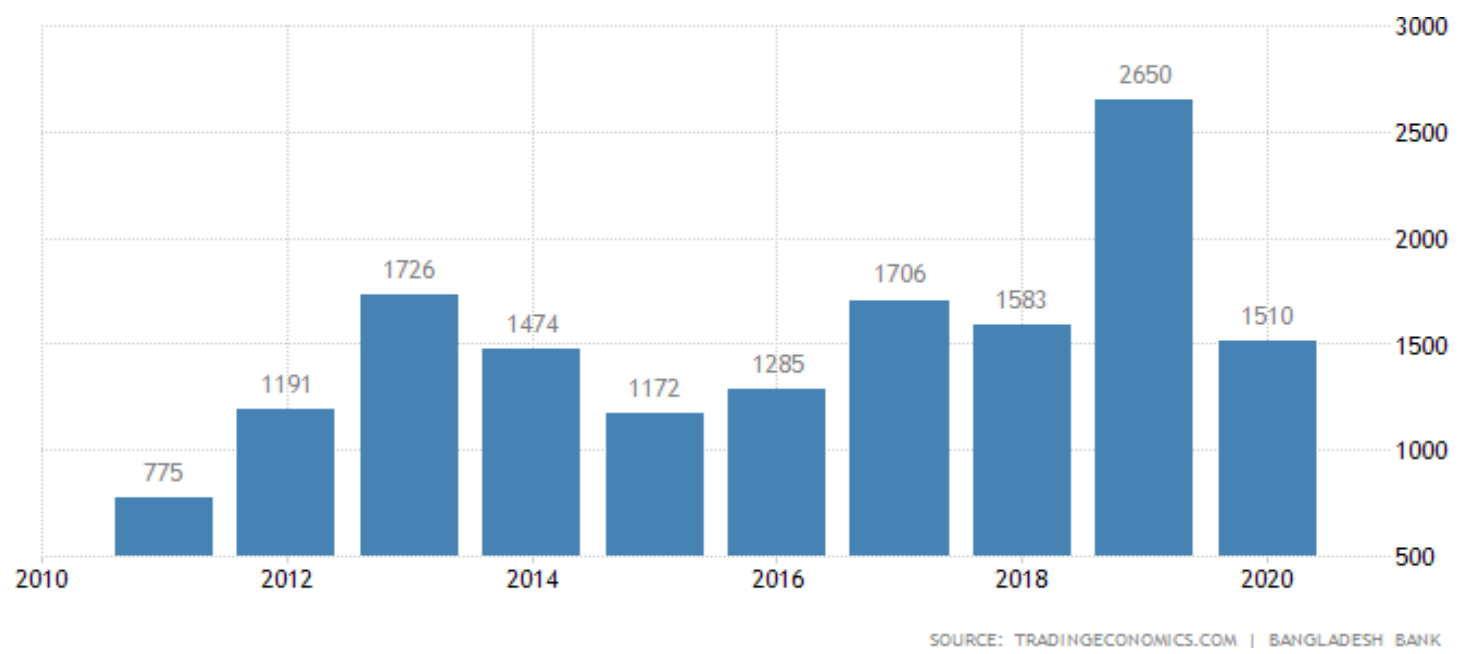

From the figure it can be said that FDI decreased to 1510.00 USD Billion in 2020. (Trading Economics, 2020) 
DOI: $\underline{10.51386 / 25815946 / \mathrm{ijsms}-\mathrm{v} 4 \mathrm{i} 4 \mathrm{p} 122}$

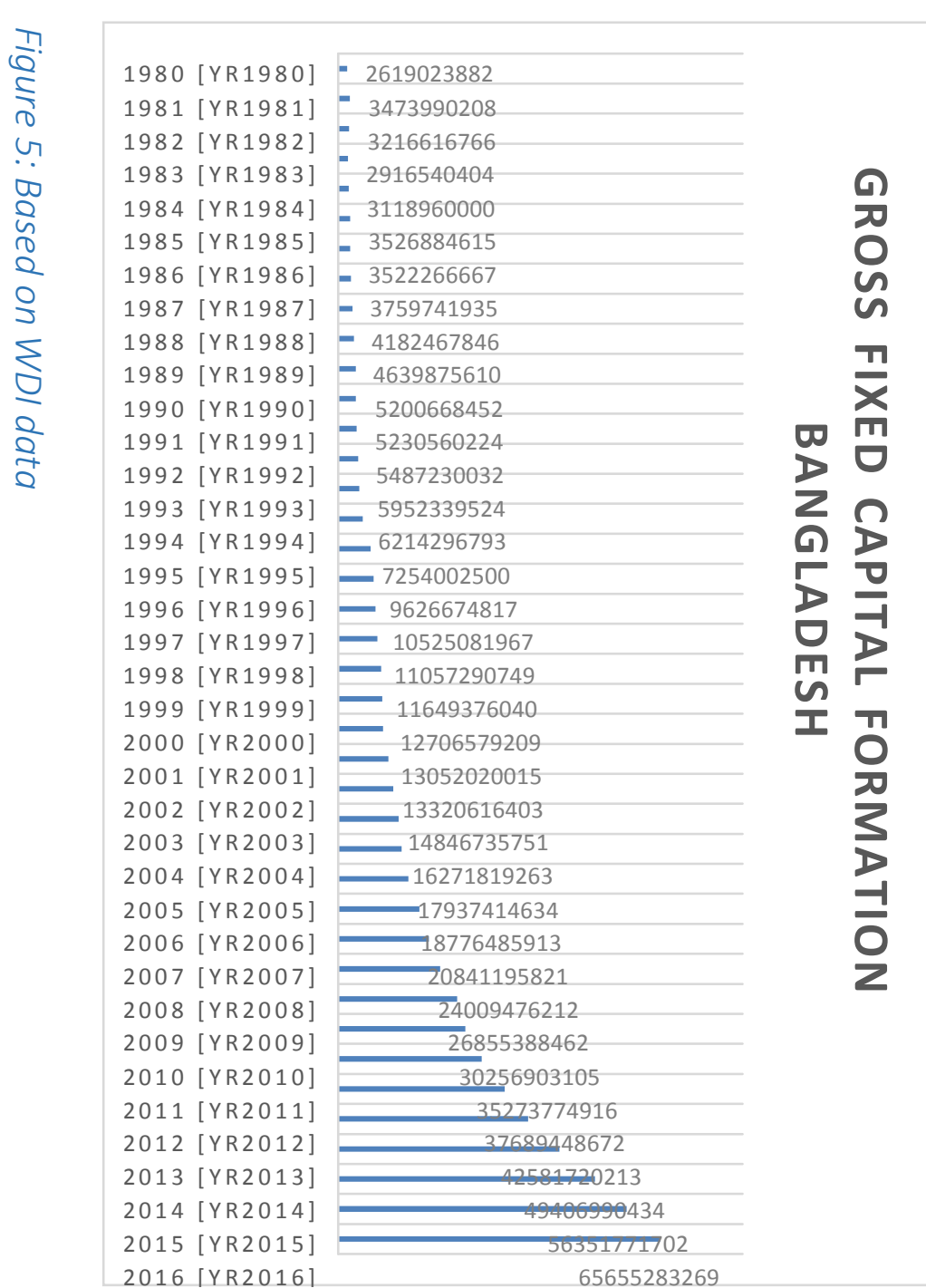


DOI: $\underline{10.51386 / 25815946 / \text { ijsms-v4i4p122 }}$
Volume: 4 Issue: 4
July to August 2021
https://www.ijsmsjournal.org

(C)

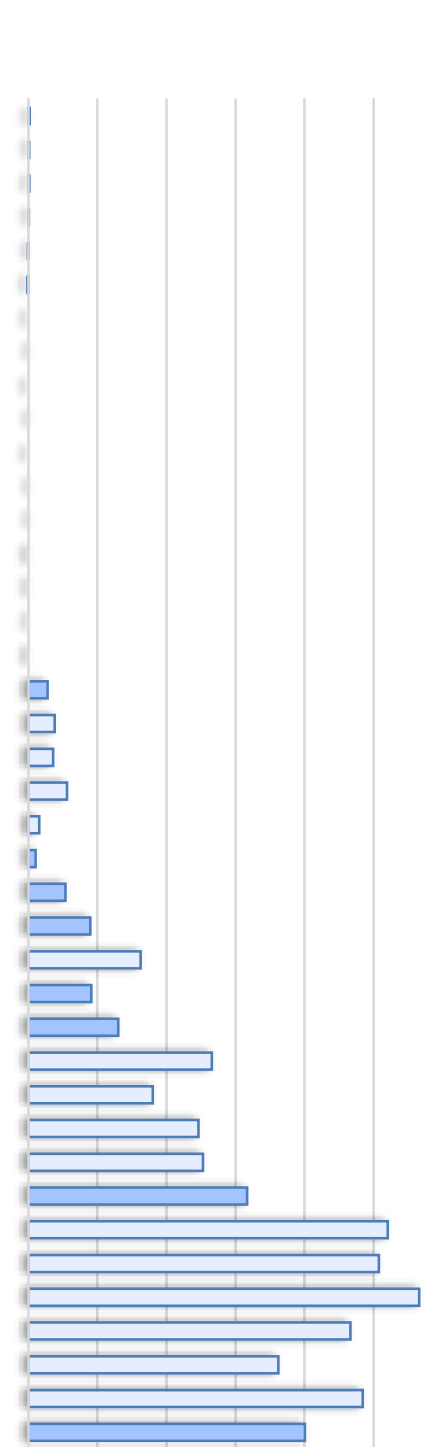


DOI: $\underline{10.51386 / 25815946 / i j s m s-v 4 i 4 p 122}$

Volume: 4 Issue: 4

\section{GDP (current US\$) Bangladesh}

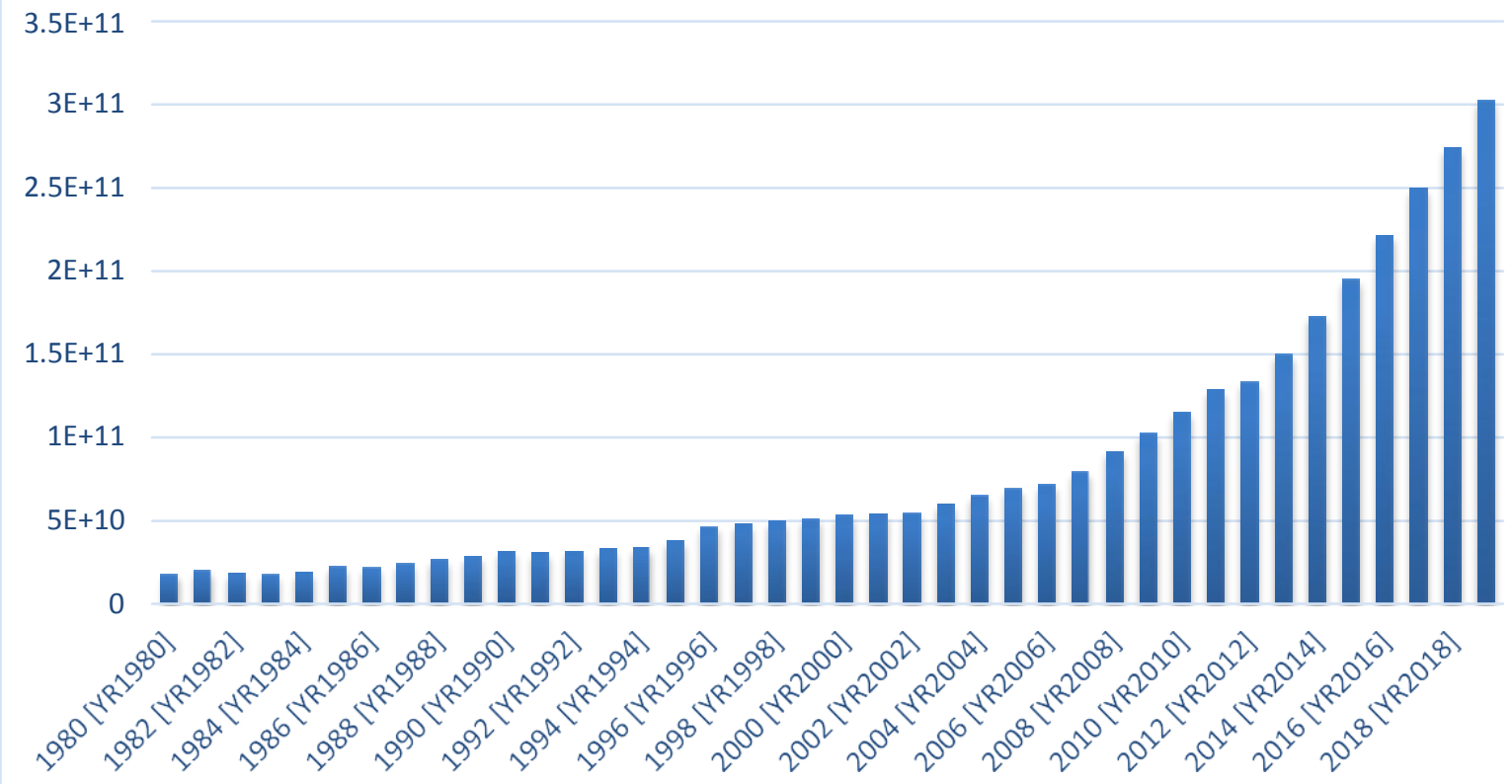

Figure 6: GDP based on WDI data

\section{Data \& data sources:}

We have taken the data of GDP, Gross Fixed Capital Formation and FDI for Bangladesh, which are also the variables for the model in this report. The dataset consists of necessary information of Bangladesh for the past 39 years.

This data has been taken from World Development Indicators (WDI) of World Bank.

\section{Empirical Model:}

As per the literature review, there are some papers where it has been discussed about the relationship of public investment and FDI on growth. This study is mainly focusing on the impact of public investment and FDI on GDP through which we can explain the quantity of influence of those variables by their estimated coefficients. This study has been done through the time series data in this regression model. The empirical model is given below:

$Y=\beta_{0}+\beta_{1} G F C F+\beta_{2} F D I+\mu$

Here we can see, this is the simple regression function and here the coefficients are not estimated. We can also see, there is a dependent variable and two independent variables. Dependent variable, $\mathrm{Y}$ is for GDP. The first independent variable is Gross Fixed Capital Formation representing public investment here while the second independent variable is FDI. which is the foreign direct investment. The last one is residual error term which is taking all therelevant variables in consideration we couldn't take.

The estimated regression model would be-

$\hat{Y}=\hat{\beta} \hat{\phi} \hat{\phi} F C F+\hat{\beta} D I+\varepsilon$

$0 \quad 1 \quad 2$

\section{Diagnostic tests:}

As we have got the time series data which is non-stationary, we need to make it stationary and for that we have done unit root test. Before doing the unit root test we have made log of the variables. After doing the unit root 
DOI: $\underline{10.51386 / 25815946 / \mathrm{ijsms}-\mathrm{v} 4 \mathrm{i} 4 \mathrm{p} 122}$

Volume: 4 Issue: 4

July to August 2021

https://www.ijjsmsjournal.org

test we have taken the first difference of the variables' dataand run the regression test. By taking first difference of the data, there won't be any non- stationarity in the variables. So in this paper we have done with four tests1. Unit root test, 2. Regression with remedial autocorrelation HAC test, 3. Autocorrelation test (serial correlation LM test) and 4. Multicollinearity test or VIF test. The test results of EVIEWS are given in the appendix section.

\section{Methodology:}

The empirical model has been shown in the previous empirical model section. Through reviewing all the literatures, we have known that there is a positive relationship of public investment and FDI on growth. Sometimes it could be negative or insignificant but we are expecting to get a positive relationship and also significant. As our objective is to find the relationship of public investment and FDI on growth of Bangladesh. According to that we havefound out the data from World Bank website.

We have found the data of Gross fixed capital formation, which can be used as public investment. It basically includes public investment. And in many papers it has been used as a variable representing the public investment. So we also can use it as public investment. The data of FDI and GDP also collected. GDP is growth rate of Bangladesh.

Here, the gross fixed capital formation and FDI are the independent variables on the other hand GDP is the dependent variable. In our study, all the variables has been taken into log function.

We have firstly taken the log function of the variables and done with the stationarity test whichis unit root test. We have got non-stationarity of the data and to remove the non-stationarity, we have taken first difference of the data. And after that we have run the regression. We have done the regression in EVIEWS and used OLS (ordinary least squares) method. We have donethe regression following GDP as dependent variable. GFCF and FDI are the independent variable. Autocorrelation test that is LM test was done and autocorrelation problem was found in the model. That was severe. We have done a remedial HAC test of regression to remove autocorrelation. After doing regression test we have done one more test. 1) Multicollinearity (VIF) test of the variables.

According to the literatures and all the information we are expecting to get a positive relationship of all the independent variables with the dependent variable. We have constructedthe model before doing regression test. Doing the regression test we have got the coefficient values, $t$-statistics, probability of F-statistics, standard errors, probability values, Adjusted R- squared values and Durbin-Watson statistics. We will discuss about some essentials of it in theresult \& result analysis part.

\section{Regression results}

\begin{tabular}{|l|l|l|l|}
\hline Variable & Coefficient & Probability & t-statistics \\
\hline LGFCF1 & 0.708056 & 0.0000 & 7.076208 \\
\hline LFDI & -5.68751552 & 0.9882 & -0.014852 \\
\hline
\end{tabular}

In our model $\mathrm{Y}$ or GDP is the dependent variable. And the intercept coefficient value is 0.005257 . The probability value of intercept parameter is 0.5218 .

Adjusted R-squared value is 0.781249 or $78.12 \%$.

Here in the regression test, Probability value of F-statistic is 0.000000 and Durbin-Watson value is 0.713611 (After doing HAC test).

\section{Result analysis:}

We have set up a model which is an empirical model. We were expecting positive relationship of the independent variable to the dependent variable. But in the estimated coefficient value, there we have found negative relationship of FDI to the GDP.

If we substitute the coefficients value in the model-

$L \hat{Y}=0.005257+0.708056 L G F C F-5.68751 L F D I+\varepsilon$ 
DOI: $10.51386 / 25815946 /$ ijsms-v4i4p122

Volume: 4 Issue: 4

July to August 2021

https://www.ijsmsjournal.org

Here, LY is log form of GDP data, LGFCF represents log form of GFCF data and LFDI meanslog form of FDI data.

The intercept value represents the value of the dependent variable, if the other variables are zero. If the independent variables are zero, then the value of $\mathrm{Y}$ would be 0.005257 .

The first independent variable here is LGFCF which is log of Gross fixed capital formation. Here this variable is showing the effect of public investment on GDP. The coefficient value is 0.708056 . We have got positive relationship of the public investment to GDP. So if there is oneunit increase in public investment, it can increase the GDP by 0.708056 unit if the other variables are fixed. Or it can be said that if there $1 \%$ increase in GFCF or public investment will cause $70.81 \%$ increase in the GDP.

The next independent variable is LFDI which log form of foreign direct investment. We can see the effect of FDI on GDP with this variable. The coefficient value for this variable is

-5.68751. We have got negative relationship of FDI to GDP. So one unit increase in FDI, will cause 5.68751 unit reduction of GDP if the other variables are constant.

On the theoretical grounds, FDI may affect growth positively because generally FDI moves from capital-rich countries to capital-scarce economies, lower rental rate of capital and increase production by developing labor productivity and introducing new technology embedded in the capital. On the other hand, FDI may affect growth negatively, as it may deteriorate or weaken competition and may corrupt the development path of the country in its own interests (Türkcan, Duman, \& Yetkiner, 2008).

Here, $\varepsilon$ is the stochastic error term in the model.

Probability values for the variables: We have seen from the result that the intercept coefficient isn't significant because the probability value is high. That is 0.5218 . It means the chances of error for the intercept coefficient value is $52.18 \%$.

The coefficient for variable LFDI is insignificant as the probability value is very high. The probability value is 0.9882 .

The coefficient value of LGFCF (public investment) is statistically significant. For this variable the probability value is 0.0000 . So there is no chance of error for the coefficient value of this variable.

Adjusted R-Squared value: This is the measure which determines if the model we have built is significant or not. From this value we can determine whether all the variables of the model are well set or not. We can also see with adjusted $\mathrm{R}$-squared value that how much the model is significant. The higher the value is, the more appropriate the model would be. From the regression result we have got the adjusted R-squared value is 0.781249 . This means the independent variables will forecast $78.12 \%$ true value of dependent variable. In other word, $78.12 \%$ dependent variable can be explained by the independent variables.

F-statistics: Basically we need to see the probability value of F- statistics. At 5\% level of significance, if the probability value of F-statistics is less than 0.05 , that means there has a significant combined effect of the independent variables to the dependent variables. In our result the probability value of F-statistics is 0.000000 . That shows the significant combined effect of independent variable to the dependent variable.

$\mathrm{D}-\mathrm{W}$ test: The value of $\mathrm{D}-\mathrm{W}$ is for checking autocorrelation in the regression model. The rangeof $\mathrm{D}-\mathrm{W}$ value is 0 to 4 . If the value is less than two, there is positive autocorrelation in the model and if there is negative autocorrelation in the model, the value would be greater than two. In our regression test, the D-W value is showing 0.713611 which is less than 2.0. It shows there is positive autocorrelation in the regression model. Doing the serial correlation test whichLM test we have come to know that the autocorrelation level is severe here because at $5 \%$ level of significance, the probability value is showing significant, so null hypothesis will be rejected. Here the null hypothesis was 'No autocorrelation'. So remedial action can be taken to remove the autocorrelation. We have done HAC test and got a regression result which has adjusted the autocorrelation problem of our model. After doing HAC test, the regression result is our mainresult.

VIF test: This test is basically for checking multicollinearity among the independent variables. Some statisticians suggest that we consider multicollinearity when VIF is greater than one. Some suggest if VIF is greater than five, then multicollinearity is severe. In our regression testwe have got the value of centered VIF for LGFCF is 2.589293 and for LFDI is 2.589293. Bothare the same value and the values are greater than one and less than five. So we can say there is no severe multicollinearity among the variables. So we don't need to go for the remedy of multicollinearity.

\section{Conclusion:}


DOI: $10.51386 / 25815946 /$ ijsms-v4i4p122

Volume: 4 Issue: 4

July to August 2021

https://www.ijsmsjournal.org

In our study we have got positive relationship of public investment to the GDP and negative relationship of FDI with the GDP. It has been observed that there is a huge impact of public investment on GDP.

$1 \%$ increase in public investment will cause $70.81 \%$ increase in GDP. That means increase of GDP mostly depends on public investments. If the public investments of our country rises, the GDP and growth rate will increase. So it can be recommended to raise up the public investments like public projects to make our GDP higher. We also know that if the public investment rises, the other sector of investments will also rise. The rise in public investment may stimulate the private investments and may be a cause of rising the employment rate as well.

We have got a negative relationship of FDI on GDP of Bangladesh. We have already known that in developing countries FDI may have positive relationship with GDP growth. But we havegot a negative relation of FDI with GDP. With that result we can say though our country is considered a developing country, gradually it's going to be a capital abundant country rather than labor abundant country. Because there is positive impacts of FDI with GDP growth in thecountries where capital is scarce and labor is abundant. In this sense it could be said that as a developing country if our country is not capital abundant, it is not capital scarce by now at least.

So, from this negative relationship of FDI with GDP, we can say our country is going to be a capital abundant country.

Further study recommendation: In this study, we didn't show the relationship of private investment to the GDP. So if further study goes on relating the impact of investment to the growth, private investment can be taken as variable to show the relationship with GDP. Relationship of public investment, private investment and FDI these three could be shown to the GDP or economic growth. Or the relationship of private investment on economic growth may be shown for Bangladesh.

More research should be done with FDI and GDP as well as economic growth. There a significant and positive relations should be found out in context of Bangladesh.

\section{References}

[1] Amadeo, K., \& Anderson, S. G. (2020, May 26). the balance. Retrieved from thebalance website :www.thebalance.com

[2] Amadeo, K., \& Brock, T. J. (2021, March 11). The Balance. Retrieved from The Balance website:www.thebalance.com

[3] Anwar, S., \& Nguyen, L. P. (2010). Foreign direct investment and economic growth in Vietnam. Asia Pacific Business Review, 16, 183-202.(2019). Bangladesh second in South Asia in GDP growth: WB. Dhaka: The Daily Star.

[4] Behname, M. (2012). Foreign Direct Investment and Economic Growth: Evidence from Southern Asia. Atlantic Review of Economics, 2 .

[5] Borensztein, E., Gregorio, J. D., \& Lee, J.-W. (1998). How does foreign direct investment affect economic growth? Journal of International Economics, 115-135.

[6] Chowdhury, M. N., Uddin, S., \& Uddin, M. M. (2015). EFFECT OF PUBLIC INVESTMENT ON ECONOMIC GROWTH IN BANGLADESH: AN ECONOMETRIC ANALYSIS. International Journal of Developingand Emerging Economies, 3, $72-97$.

[7] GHANI, E., \& DIN, M.-U. (2006). The Impact of Public Investment on Economic Growth in Pakistan . The Pakistan Development Review, 87-98.

[8] GOUMRHAR, H., \& OUKHALlOU, Y. (2017). Public Investment and GDP Growth in Developing and Advanced Countries: A Panel Data Analysis. Journal of Economics Bibliography, 78-86.

[9] Iqbal, N., Ahmad, N., Haider, Z., \& Anwar, S. (2014). Impact of foreign direct investment (FDI) on GDP: A Case study from Pakistan. International Letters of Social and Humanistic Sciences, 16,73-80.

[10] Javaid, W. (2016). Impact of Foreign Direct Investment on Economic Growth of Pakistan. Stockholm: economics department Soderton University.

[11] Kongphet, P., \& Masaru, I. (2012). The Impact of Public and Private Investment on Economic Growth: Evidence from developing Asian countries. Hiroshima, Japan: Hiroshima University.

[12] Mahembe, E., \& Odhiambo, N. (2014). FOREIGN DIRECT INVESTMENT AND ECONOMIC GROWTH: A THEORETICAL FRAMEWORK. Journal of Governance and Regulation, 3, 63-70.

[13] Milbourne, R., Otto, G., \& Voss, G. (2003). Public Investment and Economic Growth. Article inApplied Economics , 1-30.

[14] Ovi, I. H. (2020). FDI in Bangladesh falls by 32\% in H1 of 2020. Dhaka: Dhaka Tribune. Retrieved October 27, 2020, from www.dhakatribune.com 
DOI: $\underline{10.51386 / 25815946 / i j s m s-v 4 i 4 p 122}$

Volume: 4 Issue: 4

July to August 2021

https://www.ijsmsjournal.org

[15] Pettinger, T. (2016, December 14). Economics Help. Retrieved from Economics Help website:www.economicshelp.org

[16] Saidjada, K. M., \& Jahan, S. I. (2018). PUBLIC AND PRIVATE INVESTMENT NEXUS IN BANGLADESH: CROWDING-IN OR OUT? . The Journal of Developing Areas, 115-127.

[17] Swaby, R. (2007). Public Investment and Growth in Jamaica. Jamaica: Fiscal and EconomicProgramme Monitoring Dept. Bank of Jamaica.

[18] Trading Economics. (2020). Retrieved from Trading Economics website: www.tradingeconomics.com

[19] Türkcan, B., Duman, A., \& Yetkiner, I. H. (2008). How Does FDI and Economic Growth Affect Each Other? The OECD Case. International Conference On Emerging Economic Issues In A Globalizing World, Izmir (pp. 22-40). Izmir: Izmir University of Economics.

\section{Appendix:}

EVIEWS Results

Regression test (with HAC test removal of autocorrelation):

Dependent Variable: LGDP1

Method: Least Squares

Date: $02 / 25 / 21$ Time: $17: 16$

Sample (adjusted): 240

Included observations: 36 after adjustments

HAC standard errors \& covariance (Bartlett kernel, Newey-West fixed bandwidth $=4.0000$ )

\begin{tabular}{lllll}
\hline Variable & Coefficient & Std. Error & t-Statistic & Prob. \\
\hline C & 0.005257 & 0.008119 & 0.647488 & 0.5218 \\
LGFCF1 & 0.708056 & 0.100061 & 7.076208 & 0.0000 \\
LFDI1 & $-5.69 \mathrm{E}-05$ & 0.003829 & -0.014852 & 0.9882 \\
\hline R-squared & 0.793749 & Mean dependent var & 0.072278 \\
Adjusted R-squared & 0.781249 & S.D. dependent var & 0.058760 \\
S.E. of regression & 0.027483 & Akaike info criterion & -4.270863 \\
Sum squared resid & 0.024925 & Schwarz criterion & -4.138903 \\
Log likelihood & 79.87553 & Hannan-Quinn criter. & -4.224805 \\
F-statistic & 63.49956 & Durbin-Watson stat & 0.713611 \\
Prob(F-statistic) & 0.000000 & Wald F-statistic & 64.61356 \\
Prob(Wald F-statistic) & 0.000000 & & \\
\hline \hline
\end{tabular}

Regression before removal of autocorrelation:

Dependent Variable: LGDP1

Method: Least Squares

Date: 04/27/21 Time: 19:39

Sample (adjusted): 240

Included observations: 36 after adjustments

\begin{tabular}{lllll}
\hline Variant & Coefficient & Std. Error & t-Statistic & Prob. \\
\hline C & 0.005257 & 0.007655 & 0.686797 & 0.4970 \\
LGFCF1 & 0.708056 & 0.066126 & 10.70764 & 0.0000 \\
LFDI1 & $-5.69 \mathrm{E}-05$ & 0.004461 & -0.012750 & 0.9899 \\
\hline R-squared & 0.793749 & \multicolumn{2}{l}{ Mean dependent var } & 0.072278
\end{tabular}


DOI: $\underline{10.51386 / 25815946 / i j s m s-v 4 i 4 p 122}$

Volume: 4 Issue: 4

July to August 2021

https://www.ijsmsjournal.org

\begin{tabular}{llll} 
Adjusted R-squared & 0.781249 & S.D. dependent var & 0.058760 \\
S.E. of regression & 0.027483 & Akaike info criterion & -4.270863 \\
Sum squared resid & 0.024925 & Schwarz criterion & -4.138903 \\
Log likelihood & 79.87553 & Hannan-Quinn criter. & -4.224805 \\
F-statistic & 63.49956 & Durbin-Watson stat & 0.713611 \\
Prob(F-statistic) & 0.000000 & & \\
\hline
\end{tabular}

\section{Multicollinearity test:}

Variance Inflation Factors

Date: 03/01/21 Time: 20:16

Sample: 140

Included observations: 36

\begin{tabular}{llll}
\hline & $\begin{array}{l}\text { Coefficient } \\
\text { Variance }\end{array}$ & $\begin{array}{l}\text { Uncentered } \\
\text { VIF }\end{array}$ & $\begin{array}{l}\text { Centered } \\
\text { VIF }\end{array}$ \\
\hline C & $6.59 \mathrm{E}-05$ & 2.706431 & NA \\
LGFCF1 & 0.010012 & 3.357055 & 2.589293 \\
LFDI1 & $1.47 \mathrm{E}-05$ & 2.840218 & 2.589293 \\
\hline
\end{tabular}

\section{Unit Root Test:}

Null Hypothesis: LGDP has a unit root

Exogenous: Constant

Lag Length: 0 (Automatic - based on SIC, maxlag=9)

t-Statistic Prob.*

\begin{tabular}{llll}
\hline \hline Augmented Dickey-Fuller test statistic & 2.465052 & 1.0000 \\
\hline Test critical values: & $1 \%$ level & -3.610453 & \\
& $5 \%$ level & -2.938987 & \\
& $10 \%$ level & -2.607932 & \\
& & & \\
\hline
\end{tabular}

*MacKinnon (1996) one-sided p-values.

Null Hypothesis: LGDP has a unit root

Exogenous: Constant, Linear Trend

Lag Length: 0 (Automatic - based on SIC, maxlag=9)

$$
\text { t-Statistic Prob.* }
$$


DOI: $\underline{10.51386 / 25815946 / i j s m s-v 4 i 4 p 122}$

Volume: 4 Issue: 4

July to August 2021

https://www.ijsmsjournal.org

\begin{tabular}{lll}
\hline Test critical values: & $1 \%$ level & -4.211868 \\
& $5 \%$ level & -3.529758 \\
& $10 \%$ level & -3.196411
\end{tabular}

*MacKinn (1996) one-sided p-values.

Null Hypothesis: D(LGDP) has a unit root

Exogenous: Constant

Lag Length: 0 (Automatic - based on SIC, maxlag=9)

t-Statistic Prob.*

\begin{tabular}{llll}
\hline \hline Augmented Dickey-Fuller test statistic & -4.702957 & 0.0005 \\
\hline Test critical values: & 1\% level & -3.615588 & \\
& $5 \%$ level & -2.941145 & \\
& 10\% level & -2.609066 & \\
\hline
\end{tabular}

*MacKinn (1996) one-sided p-values.

Null Hypothesis: D(LGDP) has a unit root

Exogenous: Constant, Linear Trend

Lag Length: 0 (Automatic - based on SIC, maxlag=9)

\begin{tabular}{llll}
\hline & & t-Statistic & Prob.* \\
\hline Augmented Dickey-Fuller test statistic & -5.661265 & 0.0002 \\
\hline Test critical values: & $1 \%$ level & -4.219126 & \\
& $5 \%$ level & -3.533083 & \\
& $10 \%$ level & -3.198312 & \\
& & & \\
\hline
\end{tabular}

*MacKinnon (1996) one-sided p-values.

Null Hypothesis: LGFCF has a unit root

Exogenous: Constant

Lag Length: 0 (Automatic - based on SIC, maxlag=9) 
DOI: $\underline{10.51386 / 25815946 / \mathrm{ijsms}-\mathrm{v} 4 \mathrm{i} 4 \mathrm{p} 122}$

Volume: 4 Issue: 4

July to August 2021

https://www.ijjsmsjournal.org

t-Statistic Prob.*

\begin{tabular}{lll}
\hline Augmented Dickey-Fuller test statistic & 1.746499 & 0.9996 \\
\hline Test critical values: & $1 \%$ level & -3.610453 \\
& $5 \%$ level & -2.938987 \\
& $10 \%$ level & -2.607932 \\
\hline
\end{tabular}

*MacKinnon (1996) one-sided p-values.

Null Hypothesis: LGFCF has a unit root

Exogenous: Constant, Linear Trend

Lag Length: 1 (Automatic - based on SIC, maxlag=9)

\begin{tabular}{llll}
\hline & & t-Statistic & Prob. ${ }^{*}$ \\
\hline Augmented Dickey-Fuller test statistic & -3.146684 & 0.1105 \\
\hline Test critical values: & $1 \%$ level & -4.219126 & \\
& $5 \%$ level & -3.533083 & \\
& $10 \%$ level & -3.198312 & \\
& & & \\
\hline
\end{tabular}

*MacKinnon (1996) one-sided p-values.

Null Hypothesis: D(LGFCF) has a unit root

Exogenous: Constant

Lag Length: 0 (Automatic - based on SIC, maxlag=9)

t-Statistic Prob.*

\begin{tabular}{llll}
\hline \hline Augmented Dickey-Fuller test statistic & -5.648593 & 0.0000 \\
\hline \multicolumn{1}{l}{ Test critical values: } & $1 \%$ level & -3.615588 & \\
& $5 \%$ level & -2.941145 & \\
& $10 \%$ level & -2.609066 \\
\end{tabular}

*MacKinnon (1996) one-sided p-values.

Null Hypothesis: D(LGFCF) has a unit root

Exogenous: Constant, Linear Trend

Lag Length: 0 (Automatic - based on SIC, maxlag=9) 
DOI: $\underline{10.51386 / 25815946 / i j s m s-v 4 i 4 p 122}$

Volume: 4 Issue: 4

July to August 2021

https://www.ijsmsjournal.org

\begin{tabular}{lll}
\hline Augmented Pickey-Futler test statistic & -6.916064 & 0.0000 \\
\hline Test critical values: & $1 \%$ level & -4.219126 \\
& $5 \%$ level & -3.533083 \\
& $10 \%$ level & -3.198312 \\
\end{tabular}

*MacKinnon (1996) one-sided p-values.

Null Hypothesis: LFDI has a unit root

Exogenous: Constant

Lag Length: 9 (Automatic - based on SIC, maxlag=9)

t-Statistic Prob.*

\begin{tabular}{llll}
\hline \hline \multicolumn{2}{l|l}{ Augmented Dickey-Fuller test statistic } & -6.567545 & 0.0000 \\
\hline Test critical values: & $1 \%$ level & -3.737853 & \\
& $5 \%$ level & -2.991878 & \\
& $10 \%$ level & -2.635542 & \\
& & & \\
\hline
\end{tabular}

*MacKinnon (1996) one-sided p-values.

Null Hypothesis: LFDI has a unit root

Exogenous: Constant, Linear Trend

Lag Length: 1 (Automatic - based on SIC, maxlag=9)

t-Statistic Prob.*

\begin{tabular}{|c|c|c|}
\hline Augmented Dickey-Fuller test statistic & -3.153773 & 0.1107 \\
\hline $\begin{array}{l}\text { Test eritical values: } \\
-1 \% \text { level }\end{array}$ & -4.252879 & \\
\hline $5 \%$ level & -3.548490 & \\
\hline
\end{tabular}


DOI: $\underline{10.51386 / 25815946 / i j s m s-v 4 i 4 p 122}$

Volume: 4 Issue: 4

July to August 2021

https://www.ijsmsjournal.org

$10 \%$ level

$-3.207094$

*MacKinnon (1996) one-sided p-values.

Null Hypothesis: D(LFDI) has a unit root

Exogenous: Constant

Lag Length: 1 (Automatic - based on SIC, maxlag=9)

t-Statistic Prob.*

\begin{tabular}{|c|c|c|c|}
\hline \multicolumn{2}{|c|}{ Augmented Dickey-Fuller test statistic } & -4.661112 & 0.0007 \\
\hline \multirow[t]{3}{*}{ Test critical values: } & $1 \%$ level & -3.653730 & \\
\hline & $5 \%$ level & -2.957110 & \\
\hline & $10 \%$ level & -2.617434 & \\
\hline
\end{tabular}

*MacKinnon (1996) one-sided p-values.

Null Hypothesis: D(LFDI) has a unit root

Exogenous: Constant, Linear Trend

Lag Length: 8 (Automatic - based on SIC, maxlag=9)

t-Statistic Prob.*

\begin{tabular}{llll}
\hline Augmented Dickey-Fuller test statistic & -6.427524 & 0.0001 \\
\hline Test critical values: & $1 \%$ level & -4.394309 & \\
& $5 \%$ level & -3.612199 & \\
& $10 \%$ level & -3.243079 & \\
& & & \\
\hline
\end{tabular}

*MacKinnon (1996) one-sided p-values.

Serial correlation test or LM test

Breusch-Godfrey Serial Correlation LM Test:

Null hypothesis: No serial correlation at up to 2 lags

\begin{tabular}{llll}
\hline F-statistic & 5.156460 & Prob. F(2,31) & 0.0117 \\
Obs*R-squared & 8.986659 & Prob. Chi-Square(2) & 0.0112 \\
\hline
\end{tabular}

Test Equation:

Dependent Variable: RESID 
DOI: $\underline{10.51386 / 25815946 / i j s m s-v 4 i 4 p 122}$

Volume: 4 Issue: 4

July to August 2021

https://www.ijsmsjournal.org

Method: Least Squares

Date: 04/27/21 Time: 19:40

Sample: 240

Included observations: 36

Presample and interior missing value lagged residuals set to zero.

\begin{tabular}{lllll}
\hline Variable & Coefficient & Std. Error & t-Statistic & Prob. \\
\hline C & 0.012815 & 0.008055 & 1.591015 & 0.1218 \\
LGFCF1 & -0.132248 & 0.073730 & -1.793676 & 0.0826 \\
LFDI1 & 0.002398 & 0.004066 & 0.589716 & 0.5597 \\
RESID(-1) & 0.648074 & 0.204145 & 3.174568 & 0.0034 \\
RESID(-2) & -0.091454 & 0.183707 & -0.497823 & 0.6221 \\
\hline R-squared & 0.249629 & Mean dependent var & $1.93 E-19$ \\
Adjusted R-squared & 0.152807 & S.D. dependent var & 0.026686 \\
S.E. of regression & 0.024563 & Akaike info criterion & -4.446940 \\
Sum squared resid & 0.018703 & Schwarz criterion & -4.227007 \\
Log likelihood & 85.04492 & Hannan-Quinn criter. & -4.370177 \\
F-statistic & 2.578230 & Durbin-Watson stat & 1.626582 \\
Prob(F-statistic) & 0.056786 & & & \\
\hline
\end{tabular}

